\title{
Пассивация собственным окислом поверхности СdHgTe, подвергнутой жидкостному травлению
}

\author{
И.А. Краснова ${ }^{1}$, Д.В. Горшков ${ }^{1,2}$, Г.Ю. Сидоров ${ }^{2}$, Д.В. Марин ${ }^{2}$, И.В. Сабинина ${ }^{2}$ \\ ${ }^{1}$ Новосибирский государственный университет, Новосибирск, 630090, ул. Пирогова, 2 \\ ${ }^{2}$ ИФП СО РАН, Новосибирск, 630090, Лаврентьева, 13 \\ тел: (383)330-89-60, факс: (383)333-27-71, эл. почта:i.krasnova@g.nsu.ru
}

DOI 10.34077/RCSP2021-127

При изготовлении фотоприемных матриц для улучшения их частотно-контрастной характеристики (ЧКХ) необходимо уменьшить фотоэлектрическую связь между фотоприемными элементами. Поскольку влияние диффузии носителей заряда в $\mathrm{CdHgTe}$ (КРТ) увеличивается с уменьшением расстояния между фотодиодами, улучшение ЧКХ достигается за счет физического разделения при помощи травления меза-структуры. В настоящее время меза-структуры создаются с помощью жидкостного травления водным раствором $\mathrm{Br}+\mathrm{HBr}$. При таком травлении на поверхности КРТ образуется избыточный теллур, а также появляются другие дефекты, которые влияют на электрофизические свойства фотодетекторов. Для уменьшения влияния этих дефектов перспективным направлением является проведение дополнительных обработок КРТ после травления перед нанесением диэлектрика. Таким образом, целью данной работы является изучение влияния собственного окисла КРТ после жидкостного травления $\mathrm{Br}+\mathrm{HBr}$ на электрофизические свойства границы раздела КРТ $-\mathrm{Al}_{2} \mathrm{O}_{3}$.

Измерения проводились на образцах КРТ, выращенных методом молекулярно-лучевой эпитаксии, с составом $\mathrm{x}=0.22$ и концентрацией дырок $1.2 \cdot 10^{16} \mathrm{~cm}^{-3}$. Все образцы КРТ подвергались жидкостному травлению водным раствором $\mathrm{Br}+\mathrm{HBr}$. В качестве реперного был сделан образец, на который сразу после травления наносился диэлектрик без дополнительных обработок. Для изучения влияния наличия собственного окисла КРТ были изготовлены образцы, на которых собственный окисел образовывался в течение суток на воздухе или парах перекиси водорода [1]. Для изучения влияния отсутствия собственного окисла был изготовлен образец, который сразу после травления загружался в вакуумную камеру, и на него проводилось нанесение триметилалюминия (TMA) без окисления. Когда ТМА реагирует с кислородом в окисле КРТ, то он восстанавливает его с образованием оксида алюминия. После дополнительных обработок на образцы наносился диэлектрик $\left(\mathrm{Al}_{2} \mathrm{O}_{3}\right)$ методом плазменоиндуцированного атомно-слоевого осаждения при температуре роста $120^{\circ} \mathrm{C}$ [2]. Диэлектрический слой $\mathrm{Al}_{2} \mathrm{O}_{3}$ наносился одновременно на все образцы, за исключением образца, на котором проводилось нанесение 30 циклов ТМА. Затем на всех образцах изготавливались МДП структуры. На этих структурах измерялся импеданс в зависимости от напряжения и частоты при температуре жидкого азота $77^{\circ} \mathrm{K}$. Из полученных данных были найдены значения емкости диэлектрика, положения напряжения плоских зон и карты нормированной параллельной проводимости, из которых оценивались плотности поверхностных состояний.

Установлено, что у образцов с собственным окислом КРТ измеренная емкость диэлектрика меньше, чем у образцов без собственного окисла. Уменьшение емкости диэлектрика связанно с тем, что толщина диэлектрика у этих образцов больше за счет образования собственного окисла КРТ. На всех образцах наблюдается одинаковый разброс емкости диэлектрика, что говорит об однородности слоя $\mathrm{Al}_{2} \mathrm{O}_{3}$ на всех образцах. Установлено, что наибольшее по модулю значение напряжения плоских зон достигается для образца, который пролежал сутки в парах перекиси водорода после травления. А наименьшее значение достигается для образца, на котором проводилось нанесение 30 циклов ТМА, и на который после травления сразу наносился $\mathrm{Al}_{2} \mathrm{O}_{3}$. Разброс напряжений плоских зон для всех образцов одинаков. Из полученных карт нормированной параллельной проводимости было оценено, что наибольшее значение плотности поверхностных состояний достигается в образце, на котором проводилось нанесение 30 циклов ТМА. А наименьшее значение достигается для образцов с собственным окислом КРТ.

Установлено, что рост собственного окисла КРТ является перспективным способом обработки КРТ, испытавшим травление $\mathrm{Br}+\mathrm{HBr}$, для улучшения границы раздела $\mathrm{KPT}-\mathrm{Al}_{2} \mathrm{O}_{3}$.

\section{Литература}

[1] Г. Ю. Сидоров и др.// Автометрия. Т. 53, №6, 97 (2017)

[2] D.V.Gorshkov and etc.// Technical Physics Letters, 2020, Vol. 46, No. 8, pp. 741-744 